group of papers on sera and toxins. Prof. P. Masson spoke on "La multiplicité probable des syncytium de Schwann".

Papers of a general zoological or botanical nature numbered thirty-one. Prof. Marie-Victorin, J. Rousseau and J. Brunel gave the results of systematic studies of the Quebec flora. Prof. R. B. Thomson presented a new interpretation of the segmental organisation of Osmunda and Prof. H. S. Jackson described variations in the short-cycle rusts; with their colleagues and students they presented a series of other papers on plant anatomy and mycology. Dr. J. H. Craigie gave an exhaustive account of the epidemiology of wheat stem rust. Dr. J. W. McArthur presented data on tomatoes which are of great significance for general theories of the inheritance of quantative characters. Dr.
L. O. Gaiser showed the occurrence of different chromosome numbers in various wild populations of Liatris punctata. Prof. A. H. R. Buller reviewed our knowledge of the sclerotia of the higher fungi. Prof. G. H. Scarth and J. Levitt described a method of measuring water permeability of freed plant protoplasts and gave new data on the problem of cell permeability in relation to hardiness.

A dinner in honour of Prof. Wilson Smith, professor of botany at McMaster University, who is retiring this year, and various field excursions were interesting features for this Section.

The social arrangements made by McMaster University and local residents, and the facilities for accommodation, exhibits and meetings provided by the splendid new buildings of the University were much appreciated.

\title{
Obituary
}

\section{Prof. B. L. Robinson}

$\mathrm{F}^{2}$ LORISTIC botany suffered a heavy loss by the death on July 27 of Benjamin Lincoln Robinson. Born at Bloomington, Illinois, on November 8, 1864, he graduated A.B. at Harvard in 1887, and then studied under de Bary at Strassburg, where he took the Ph.D. in 1889. His early work was anatomical, especially on unusual stem-anatomy; his thesis was on the stem-anatomy of Phytocrene macrophylla.

Returning to Harvard, Robinson became assistant in the Gray Herbarium under Sereno Watson, and on Watson's death in 1892 was appointed curator. The development of the Herbarium and the continuation of the taxonomic researches on American botany begun by Gray and continued by Watson have been Robinson's life-work. He found the Herbarium poorly housed, inadequately equipped, with a meagre endowment, and no definite status in the University. By the aid of generous donors he was able, during the years 1909-15, gradually to replace the little old building by an imposing modern structure which has been described as the safest and most conveniently arranged and best equipped herbarium building in the world. The endowment in 1899, by Mrs. Gray, of an Asa Gray professorship of systematic botany, of which Robinson was the first incumbent, added instruction to the functions of the Herbarium.

Two important pieces of work demanded attention when Robinson became curator-the completion of Gray's "Synoptical Flora of North America", and a much needed revision of Gray's "Manual of Botany". The former, with the aid of several experienced botanists, was completed in 1895-97, and the latter in conjunction with M. L. Fernald in 1908.

The results of Robinson's work and that of his assistants, on the floras of North America, Mexico and tropical South America, are embodied in a long series of papers in the Proceedings of the American Academy of Arts and Sciences and other periodicals. The substantial volumes of the reprints collected in the convenient form of "Contributions from the Gray Herbarium" are a monument to their industry. Robinson was specially fond of the Compositæ, and his "Revision of the genus Brickellia" was the first of the larger "Memoirs of the Gray Herbarium" begun in 1907.

Robinson's interest in local and regional botany found expression in the New England Botanical Club started in Boston in 1895, and for thirty years after its inception in $\mathbf{1 8 9 9}$ he edited its journal, Rhodora. The Club collection lodged in the Gray Herbarium numbers more than 150,000 sheets.

British botanists showed their appreciation of Robinson's work by electing him to the foreign membership of the Linnean Society of London in 1922. His colleagues and friends at home and abroad will regret the passing of an eminently sane critical botanist and a courteous and kindly gentleman.

\section{A. B. RENDLE.}

WE regret to announce the following deaths :

Lieut.-Colonel H. W. Acton, C.I.E., formerly director of the School of Tropical Medicine, Calcutta, on August 23, aged fifty-two years.

Prof. Henry Briggs, O.B.E., Hood professor of mining in the University of Edinburgh since 1924, and professor of mining in Heriot-Watt College since 1919, on August 24, aged fifty-two years.

Prof. E. Jeanselme, emeritus professor in the faculty of medicine in the University of Paris, known for his work on syphilis, leprosy, and the history of medicine, aged seventy-seven years. 